Available online @ https://jiem.jnnce.ac.in

https:www.doi.org/10.37314/JJEM.2021.050107

Indexed in International Scientific Indiexing (ISI)

Impact factor: 1.025 for 2018-19

Published on: 30 September 2021

\title{
Ground Water Study of Shivamogga City
}

\author{
Mohamed Ibrahim ${ }^{1}$ ， Kishan Kumar K.L ${ }^{2}$, Saqeeb Ulla Khan ${ }^{3}$ \\ 1, 2,3 Department of Civil Engineering, \\ JNN College of Engineering, Shivamogga, Karnataka, India
}

mohamedibrahim@jnnce.ac.in, kishan.k1.568@gmail.com, saqibkhan955@gmail.com

\begin{abstract}
In recent years, the increasing threat to groundwater quality due to human activities has become a matter of great concern. A vast majority of groundwater quality problems present today are caused by contamination and by over- exploitation, or by combination of both. Rapid urbanization and industrialization in India has resulted in steep increase of generation of wastes. Due to lack of adequate infrastructure and resources the waste is not properly collected, treated and disposed; leading to accumulation and infiltration causing groundwater contamination.

The chemical quality of ground water collected from 20 stations of and around Shivamogga during April 2019 indicates that most of the parameters are in acceptable limit and some of them are in permissible limit and very few of them are beyond limits as evaluated against drinking water quality requirements [BIS 10500, (1991) \& WHO (1996) Standards]. The Report presents the environmental profiles of Shivamogga city and Problem areas are identified and their groundwater quality status. Alkalinity and Hardness are the main water quality issues in the Shivamogga city. Considering the competing demand on this scarce resource, the report highlights the judicious use of groundwater and also remedial measures needed to overcome the problems.
\end{abstract}

Keywords: Ground Water, Contaminants, Treatment, Limits

\section{Introduction}

The urbanization rate in India is very fast. It has increased from $10.84 \%$ in 1901 to $28.5 \%$ in 2001. According to the Census figure of 2001, the number of class I cities and class II towns was around900. Unregulated growth of urban areas, without infrastructural services for proper collection, transportation, treatment and disposal of domestic waste water led to increased pollution and health hazards. Fast urbanization followed by increase in prosperity resulting in steep increase in waste generation.

As per the latest estimate of Central Pollution Control Board, about 29,000 million litres/day of wastewater generated from class-I cities and class-II towns out of which about $45 \%$ (about $13000 \mathrm{mld}$ ) is generated from 35 metro-cities alone. The collection system exists for only about $30 \%$ of the wastewater through sewer line and treatment capacity exists for about 7000 million litres/day.

The quality of groundwater depends on a large number of individual hydrological, physical, chemical and biological factors. Generally higher proportions of dissolved constituents are found in groundwater than in surface water because of greater interaction of ground water with various materials in geologic strata. The water used for drinking purpose should be free from any toxic elements, living and nonliving organism and excessive amount of minerals that may be hazardous to health. Some of the heavy metals are extremely essential to humans, for example, Cobalt, Copper, etc., but large quantities of them may cause physiological disorders. The contamination of ground water by heavy metals has assumed great significance during recent years due to their toxicity and accumulative behavior. 
These elements, contrary to most pollutants, are not biodegradable and undergo a global eco-biological cycle in which natural waters are the main pathways. The determination of the concentration levels of heavy metals in these waters, as well as the elucidation of the chemical forms in which they appear is a prime target in environmental research today.

A vast majority of groundwater quality problems are caused by contamination, over-exploitation, or combination of the two. Groundwater pollution. These concentrated sources can be easily detected \& regulated but the more difficult problem is associated with diffuse sources of pollution like leaching of agrochemicals \& animal wastes subsurface discharges from latrines \& septic tanks \& infiltration of polluted urban run-off $\&$ sewage where sewerage does not exists or defunct. Diffuse sources can affect entire aquifers, which is difficult to control \& treat. The only solution to diffuse sources of pollution is to integrate land use with water management. Once pollution has entered the sub-surface environment, it may remain concealed for many years, becoming dispersed over wide areas \& rendering groundwater supplies unsuitable for human uses.

\section{Literature Survey}

Nagalambika et al., [1] in their two-year study of the seasonal variations in fluoride concentration was carried out from November 2006 to October 2008 in the groundwater of Mysore city with five zones. The fluoride concentration in the water samples of east and west zones showed significant seasonal changes during both the years. However in north, south and central zones, fluoride concentration did not establish any variations in both the years. The highest fluoride value of $0.46 \mathrm{mg} / \mathrm{L}$ was recorded in the west zone and the lowest of $0.22 \mathrm{mg} / \mathrm{L}$ in the east zone. The probable causes for such variations in fluoride concentration in these groundwater samples have been discussed.
Suresh et al., [2] carried out hydro geo-chemical investigations in Sandur taluk, a major mining taluk of Bellary district in Karnataka. Water samples of 43 bore wells at various locations were collected and analyzed for its suitability for domestic and irrigation purposes. Most of the physico-chemical parameters were within the permissible limits of WHO and ISI standards for drinking water. However, some samples show very high NO3, $\mathrm{Cl}$ and $\mathrm{F}$ content than the desirable limit. The data was also subjected to various hydro chemical interpretations. According to USSL classification, the groundwater of the study area falls under mostly three types as C2 S1, C2 S2 and C3 S1. In eight locations it was found to be of C3 S2 type with moderately high salinity. The value of SAR was in the range of excellent to good type. Based on the Piper trilinear diagram, the study area was characterized by water having temporary hardness. Fluoride was most dominant ion responsible for the contamination of the groundwater. Ten samples of the study area were prone to excess fluoride and not suitable for drinking. Water samples were also subjected to microbiological analysis. Few samples were found to be highly contaminated with coliforms while most of the samples were suitable for human consumption.

IS 10500:2012 Indian Standards Drinking Water specifications [3]: This standard prescribes the requirements and the methods of sampling and test for drinking water. Ground Water information booklet, Shivamogga District, Karnataka[4] highlights the ground water scenario, its resource potential, quality aspects, recharge - discharge relationship, etc. The fourth edition of the World Health Organization's (WHO) Guidelines [5] for drinking-water quality (GDWQ) builds on over 50 years of guidance by WHO on drinking water quality, which has formed an authoritative basis for the setting of national regulations and standards for water safety in support of public health. 
3. Tests Conducted and Equipments used in the Study

The tests conducted, method adopted and the instruments used for conducting the tests are presented in Table 1.

Table 1: Tests conducted and equipment's used in the

\begin{tabular}{|c|c|c|c|}
\hline \\
\hline \# & Parameter & Method & Instruments \\
\hline 1 & $\begin{array}{c}\text { Electrical } \\
\text { Conductivity }\end{array}$ & Electrometric & $\begin{array}{l}\text { Conductivity } \\
\text { Meter }\end{array}$ \\
\hline 2 & $\mathrm{pH}$ & Electrometric & $\mathrm{pH}$ meter \\
\hline 3 & Turbidity & Electrometric & $\begin{array}{c}\text { Neohelometer's } \\
\text { turbidity } \\
\text { meter }\end{array}$ \\
\hline 4 & $\begin{array}{l}\text { Dissolved } \\
\text { Oxygen }\end{array}$ & $\begin{array}{c}\text { Titration by } \\
\mathrm{Na}_{2} \mathrm{~S}_{2} \mathrm{O}_{3}\end{array}$ & \multirow{7}{*}{$\begin{array}{c}\text { Titration } \\
\text { Equipment's }\end{array}$} \\
\hline 5 & Acidity & $\begin{array}{c}\text { Titration by } \\
\mathrm{NaOH}\end{array}$ & \\
\hline 6 & Alkalinity & $\begin{array}{c}\text { Titration by } \\
\mathrm{H}_{2} \mathrm{SO}_{4} \\
\end{array}$ & \\
\hline 7 & Chlorides & $\begin{array}{l}\text { Titration by } \\
\mathrm{AgNO}_{3}\end{array}$ & \\
\hline 8 & Hardness & $\begin{array}{l}\text { Titration by } \\
\text { EDTA }\end{array}$ & \\
\hline 9 & Calcium & $\begin{array}{c}\text { Titration by } \\
\text { EDTA }\end{array}$ & \\
\hline 10 & Magnesium & $\begin{array}{l}\text { Titration by } \\
\text { EDTA }\end{array}$ & \\
\hline
\end{tabular}

\section{Results}

The experimental results of the samples collected from different locations are presented in Table 2.

The various parameters and the corresponding treatment is shown in Table 3.

The Permissible limits for dissolved oxygen are shown in Table 4.

\section{Conclusion}

It has been found that the water is slightly acidic and presence of $\mathrm{CaCO}_{3}$ has been noticed which results in the hardness of water.

From the above consideration, it can be concluded that there might be a possibility of aquifer media experiencing rock water interaction. The results from this study shows that the rocks enriched in carbonate minerals and feldspars, when subjected to chemical weathering will ultimately lead to the oversaturation of $\mathrm{CaCO}_{3}$ and $\mathrm{MgCO}_{3}$.

From the various experiments it can be concluded that some of the water samples have crossed the acceptable limit prescribed by Indian standard in some of the parameters, but still the values are under the permissible limit in the absence of alternative source.

The groundwater of Shivamogga is only prescribed for drinking purpose in case other source of drinking water is not available. Another good option is to treat the water before using it for drinking purpose.

Treatments for various parameters are prescribed in their respective explanation part.

Water supplied by the municipal of Shivamogga is way better than ground water of Shivamogga. It's suggested to use municipal water for drinking purpose; ground water can be used for other various purposes. Since the ground water of Shivamogga is safe for all purpose except for drinking. 
Table 2: Experimental Results

\begin{tabular}{|c|c|c|c|c|c|c|c|c|c|c|c|}
\hline & $\begin{array}{l}\text { Sample } \\
\text { Name }\end{array}$ & $\frac{I}{2}$ & 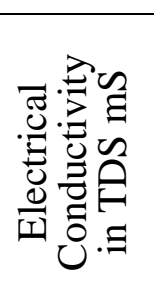 & 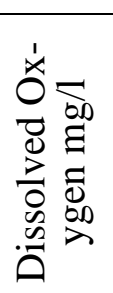 & 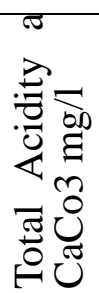 & 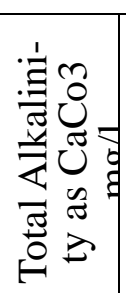 & 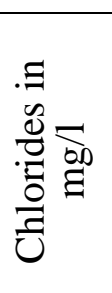 & 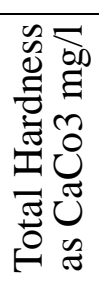 & 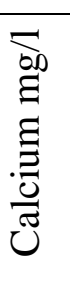 & 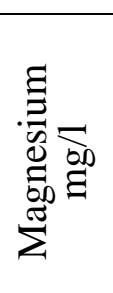 & 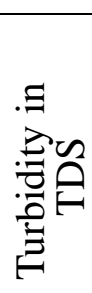 \\
\hline 1 & Sudebailu & 7.05 & 892.8 & 5.3 & 176 & 258 & $\begin{array}{l}107 . \\
09\end{array}$ & 462 & $\begin{array}{l}112 \\
.8\end{array}$ & 43.2 & 9 \\
\hline 2 & Vidya Nagar & 6.79 & 362.7 & 4.4 & 114 & 150 & $\begin{array}{l}96.4 \\
5\end{array}$ & 168 & $\begin{array}{l}52 . \\
8\end{array}$ & 28.8 & 23 \\
\hline 3 & Kote Area & 6.73 & 344.1 & 5.8 & 88 & 182 & $\begin{array}{l}59.5 \\
7\end{array}$ & 118 & $\begin{array}{l}31 . \\
2\end{array}$ & 32 & 5 \\
\hline 4 & SantheKadur & 7.21 & 949.22 & 6.7 & 104 & 264 & $\begin{array}{l}314 . \\
88\end{array}$ & 540 & $\begin{array}{l}148 \\
.8\end{array}$ & 134.4 & 1 \\
\hline 5 & Ragigudda & 6.61 & 675.18 & 6.3 & 102 & 138 & $\begin{array}{l}219 . \\
85\end{array}$ & 370 & $\begin{array}{l}80 . \\
8\end{array}$ & 134.4 & 24 \\
\hline 6 & RML Nagar & 7.21 & 502.2 & 7.3 & 62 & 204 & $\begin{array}{l}107 . \\
09\end{array}$ & 268 & $\begin{array}{l}56 . \\
8\end{array}$ & 100.8 & 19 \\
\hline 7 & $\begin{array}{l}\text { Vinobha Na- } \\
\text { gar }\end{array}$ & 6.83 & 221.34 & 5.4 & 66 & 104 & $\begin{array}{l}70.9 \\
2\end{array}$ & 160 & 24 & 80 & 4 \\
\hline 8 & $\begin{array}{l}\text { JNNCE Col- } \\
\text { lege }\end{array}$ & 7.62 & 75.64 & 6.2 & 12 & 54 & $\begin{array}{l}17.0 \\
2\end{array}$ & 54 & 8.8 & 25.6 & 7 \\
\hline 9 & Gopala & 7.10 & 393.7 & 6.7 & 50 & 162 & $\begin{array}{l}83.6 \\
8\end{array}$ & 302 & $\begin{array}{l}60 . \\
8\end{array}$ & 120 & 7 \\
\hline 10 & Bus Stand & 8.01 & 1182.34 & 7.0 & 24 & 174 & $\begin{array}{l}309 . \\
21\end{array}$ & 378 & $\begin{array}{l}84 . \\
8\end{array}$ & 132.8 & 30 \\
\hline 11 & Tank Mohalla & 7.55 & 80.6 & 6.3 & 12 & 44 & $\begin{array}{l}31.2 \\
0\end{array}$ & 110 & $\begin{array}{l}16 . \\
8\end{array}$ & 54.4 & 13 \\
\hline 12 & Ilyas Nagar & 8.78 & 71.92 & 7.3 & 14 & 42 & $\begin{array}{l}28.3 \\
7\end{array}$ & 110 & 12 & 64 & 9 \\
\hline 13 & Alkola Circle & 7.06 & 954.8 & 4.9 & 170 & 364 & $\begin{array}{l}38.6 \\
9\end{array}$ & 566 & $\begin{array}{l}111 \\
.2\end{array}$ & 230.4 & 17 \\
\hline 14 & $\begin{array}{l}\text { Manjunatha } \\
\text { Talkies }\end{array}$ & 7.43 & 682.00 & 4.9 & 88 & 328 & $\begin{array}{l}148 . \\
93\end{array}$ & 362 & $\begin{array}{l}86 . \\
4\end{array}$ & 116.8 & 15 \\
\hline 15 & $\begin{array}{l}\text { Railway Sta- } \\
\text { tion }\end{array}$ & 7.10 & 804.76 & 6.6 & 118 & 316 & $\begin{array}{l}211 . \\
34\end{array}$ & 472 & $\begin{array}{l}73 . \\
6\end{array}$ & 230.4 & 14 \\
\hline 16 & Jail Circle & 6.92 & 381.92 & 6.4 & 98 & 158 & $\begin{array}{l}83.6 \\
8\end{array}$ & 172 & $\begin{array}{l}43 . \\
2\end{array}$ & 51.2 & 16 \\
\hline 17 & $\begin{array}{l}\text { PESIT Col- } \\
\text { lege }\end{array}$ & 7.50 & 680.76 & 7.6 & 62 & 234 & $\begin{array}{l}165 . \\
95\end{array}$ & 390 & 88 & 136 & 10 \\
\hline 18 & Wadi-E-Huda & 7.05 & 436.48 & 5.5 & 82 & 138 & $\begin{array}{l}134 . \\
75\end{array}$ & 308 & $\begin{array}{l}61 . \\
6\end{array}$ & 152 & 14 \\
\hline 19 & Malawagoppa & 7.19 & 1376.4 & 6.8 & 118 & 260 & $\begin{array}{l}235 . \\
45\end{array}$ & 638 & $\begin{array}{l}238 \\
.4\end{array}$ & 33.6 & 12 \\
\hline 20 & Purle & 6.77 & 647.28 & 3.8 & 160 & 198 & $\begin{array}{l}229 . \\
78\end{array}$ & 384 & 72 & 163.2 & 7 \\
\hline \multicolumn{2}{|c|}{ Permissible limits } & $\begin{array}{l}6.5- \\
8.5\end{array}$ & $\begin{array}{l}500- \\
2000 \\
\end{array}$ & & $\begin{array}{l}200- \\
600\end{array}$ & $\begin{array}{l}200- \\
600\end{array}$ & $\begin{array}{l}250- \\
1000\end{array}$ & $\begin{array}{l}200- \\
600\end{array}$ & $\begin{array}{l}75- \\
200 \\
\end{array}$ & $\begin{array}{l}30- \\
100\end{array}$ & $1-5$ \\
\hline
\end{tabular}




\begin{tabular}{|c|c|}
\hline & Safe (acceptable limits) \\
\hline & $\begin{array}{c}\text { Permissible in absence of } \\
\text { alternative source }\end{array}$ \\
\hline unsafe \\
\hline & $\begin{array}{c}\text { Out of permissible limits but } \\
\text { still consumable }\end{array}$ \\
\hline
\end{tabular}

Table 3: Parameters and treatment

\begin{tabular}{|c|c|}
\hline Parameter & Treatment \\
\hline Electrical Conductivity & Reverse Osmosis, Distillation, Deionization \\
\hline $\mathrm{pH}$ & Addition of white Vinegar or Citric acid \\
\hline Turbidity & Alum, Gypsum, $\mathrm{FeCl}_{3}$ \\
\hline Dissolved Oxygen & Activated Carbon \\
\hline Acidity & Use of Calcite \\
\hline Alkalinity & Using Neutralizing agents \\
\hline Chlorides & Reverse Osmosis, Distillation, Activated \\
& Charcoal \\
\hline Hardness & Water Softener Ion Exchanger, RO \\
\hline Calcium & Water Softener \\
\hline Magnesium & Water Softener \\
\hline
\end{tabular}

Table 4: Permissible limits for dissolved oxygen

\begin{tabular}{|c|c|c|}
\hline Classification & Type of use & $\begin{array}{c}\text { Limit of } \\
\text { DO (mg/l) }\end{array}$ \\
\hline Class A & Drinking Water Without Treatment & 6 \\
\hline Class B & Outdoor Bathing & 5 \\
\hline Class C & Drinking Water with Treatment & 4 \\
\hline Class D & Fish Culture and Wild Life & 4 \\
\hline
\end{tabular}

Source: IS 2296 :1989

\section{References}

2. T. Suresh and N.M. Kottureshwara, Quality

1. C. Nagalambika, S. Mahadeva Murthy, T.

S. Harsha and N.Lakshmidevi. 2012. Studies on Groundwaters of Mysore City with Special Reference to Fluoride Concentration, Nature Environment and Pollution Technology, An International Quarterly Scientific Journal, Vol. 11 No. 4, 2012, pp. 711-716. of Ground Water in Selected Areas of Sandur Taluk in Karnataka State, India. RASAYAN J. Chem. Vol.2, No.2, 2009, pp. 350-360.

3. IS 10500:2012 Indian Standards, Drinking Water specifications, (second revision) Bureau of Indian Standards, New Delhi, 110002. 
4. Ground Water Information Booklet, 5. Guidelines for Drinking Water Quality, Shivamogga District, Karnataka by Central Fourth Edition, World Health Organization, Ground Water Board -2012. Geneva, 2011. 